\section{Dr. H. Moore}

Dr. Harold Moore, who has just taken office as president of the Institute of Metals, was born in 1878, and began his metallurgical career as a pupil of the late Dr. J. E. Stead. In 1901 he became research metallurgist at the Parkhead steel works of William Beardmore and Co., Ltd., where his work in connexion with the manufacture and heat-treatment of armourplate developed his interest in alloy steels. Rapid progress was then being made in the application of nickel-chromium steels for this and other purposes. Later work has shown that some of the methods of heat-treatment then developed empirically must have had the effect of suppressing temper brittleness, a trouble that was not clearly defined until some years later. In 1904 Dr. Moore joined, as chief metallurgist, the Research Department at Woolwich Arsenal, where he remained for twenty-eight years, from 1919 until 1932, being director of metallurgical research. As chief metallurgical adviser for many years to the War Office and the Ordnance Department of the Admiralty, Dr. Moore had a wide experience of Service problems both on the manufacturing and the applications sides. In 1922 a research on the casting of brass ingots was undertaken under his direction for the British Non-Ferrous Metals Research Association, and this led to a gradually increasing co-operation between the Association and the Research Department, Woolwich, which undertook work on lead cable sheathing (in the course of which the widely used B.N.F. ternary alloys of lead were developed), electrodeposition of nickel, tin coatings, etc. In 1932 Dr. Moore accepted the offer of the post of director of the British Non-Ferrous Metals Research Association, which had become vacant through the election of Dr. R. S. Hutton as Goldsmith's professor of metallurgy in the University of Cambridge.

\section{Prof. William Buckland, I784-I856}

MaRch 12 marks the one hundred and fiftieth anniversary of the birth of the Rev. William Buckland, geologist and father of the famous naturalist, Frank Buckland. William Buckland was born at Tiverton, Devonshire, on March 12, 1784. He went up to Corpus Christi College, Oxford, from Winchester in 1801 and was elected a fellow of his College in 1808. Five years later he was appointed Oxford reader in mineralogy and was elected a fellow of the Geological Society, of which body he was twice president. He was elected a fellow of the Royal Society in 1818, in which year he was appointed first professor of geology at Oxford. Upon the discovery of the Kirkdale Cave, Pickering, Yorkshire, in 1821, in which the fossil bones of numerous Tertiary animals were found, Buckland made a careful examination, and in 1822 the Royal Society awarded him its Copley medal for his account of the study of the remains found in the cave. In 1823 he supplemented his observations on Kirkdale Cave by publishing "Reliquiæ Diluvianæ". A century ago he was working at his well-known Bridgewater Treatise (awarded for an essay "On the power, wisdom, and goodness of God, as manifested in the creation"),
"Geology and Mineralogy considered with reference to Natural Theology", which was published in 1836. After his appointment as Canon of Christ Church in 1825, he lived at the House for twenty years, and it was in a wall in the Canon's garden that he tested the power of toads to live when immured in rock cavities. In 1845 he was made Dean of Westminster. The strain of his new work at Westminster undoubtedly shortened his life, and he died and was buried at Islip in August 1856.

\section{Research on Influenza}

ThE extermination of the polecat in Great Britain was carried out with deplorable success in the eighteenth and early nineteenth centuries. It is fortunate for the progress of knowledge that it survived in the domesticated form of the ferret, which was of immense service in solving the problem of the cause and prevention of dog distemper, and now promises to be of equal value in studying human influenza. The facts so far ascertained at the National Institute for Medical Research at Hampstead are not conclusive but they are certainly very suggestive. Dr. P. P. Laidlaw, Dr. C. H. Andrewes and Dr. W. Smith have found that washings from the noses of human cases of influenza, after passing through a bacteria-proof filter, cause a characteristic febrile and catarrhal attack when instilled. into the noses of ferrets, which by similar means can be carried on to other ferrets in series. No other animal which has been tried is susceptible in the same way, and no other method of inoculation will infect the ferretso much does progress rest on technique. Recovered ferrets are immune and their blood will neutralise the infective material, as will the blood of human beings who have passed through an attack. The facts fit in well with the idea that uncomplicated human influenza is relatively a trivial disease and that when the cyclical epidemics fall in the summer months they attract no great attention: if they come in the winter they give a severe affection with a substantial mortality due to the secondary invasion of the lungs by Pfeiffer's bacillus, streptococci and perhaps pneumococci. In the 'influenza' of pigs studied by Shope in America, the virus causing the primary disease is of practical importance only because it allows infection by the secondary bacillus.

\section{Petrol from Coal}

THE liquid products of the carbonisation of coal at low temperatures have been disappointing because they lack the chemical characteristics which give special value to high temperature products. Thus, low temperature tar oils have had to be used as boiler fuel oils-which is the lowest use to which a manufactured oil can be put. It is, however, satisfactory to know that the Admiralty has been able to use such oils as fuel and thus satisfy its needs from British coal. Researches now proceeding may provide new outlets for low temperature oils. As a source of motor spirit, low temperature products are also at a disadvantage, the crude spirit being troublesome to refine owing to a high proportion of unsaturated compounds liable to form gums on the 